\title{
PEMBERDAYAAN USAHA KECIL DAN MENENGAH KAIN TENUN CEPUK DI KECAMATAN NUSA PENIDA KABUPATEN KLUNGKUNG, BALI
}

\author{
Ni Luh Sayang Telagawathi \\ Jurusan Manajemen, Universitas Pendidikan Ganesha \\ Singaraja, Bali \\ e-mail: gemilangsuryawan@gmail.com
}

\begin{abstract}
Abstrak
Artikel ini mengelaborasi model-model pemberdayaan Usaha Kecil dan Menengah (UKM) yang bisa dikembangkan di tengah pengerajin kain tenun cepuk di Desa Tanglad dan Desa Pejukutan Kecamatan Nusa Penida, Kabupaten Klungkung, Bali. Dengan menggunakan perspektif pemberdayaan dan kewirausahaan serta metode penelitian partisipatif yang emansipatoris dengan melibatkan para pengerajin dalam merancang dan melaksanakan program. Artikel ini mengidentifikasi ada tiga model pemberdayaan industri kecil kain tenun cepuk. Ketiga model pemberdayaan tersebut adalah pemberdayaan pemasaran, pemberdayaan sumber daya manusia, dan pemberdayaan kelompok pengerajin. Ketiga model pemberdayaan tersebut pada dasarnya melibatkan tiga komponen penting dalam usaha pemberdayaan industri kerajinan kain tenun cepuk yaitu: pemerintah, swasta, komponen pariwisata, dan sudah tentu pengerajin kain cepuk itu sendiri.
\end{abstract}

Kata kunci: model pemberdayaan, usaha kecil dan menengah, kewirausahaan, kain tenun cepuk

\begin{abstract}
This article elaborates on the model for empowerment of UKM (Usaha Kecil dan Menengah), small and medium enterprises that can be developed in the Desa Tanglad (Tanglad Village) and Desa Pejukutan (Pejukutan Village) District of Nusa Penida, Klungkung, Bali. Using entrepreneurial perspective and empowerment and research methods, the emancipatory with participatory involve designing the craftsmen hearts and doing programs. This article identifyed three empowerment model for UKM (Usaha Kecil dan Menengah). The three models empowerment is empowerment for marketing, human resources empowerment, and empowerment group and craftsmen. All three models of the Empowerment essentially involved three components are: government, private, tourism component, of course craftsmen.
\end{abstract}

Keywords: empowerment model, UKM (Usaha Kecil dan Menengah), entrepreneurship, tenun cepuk

\section{PENDAHULUAN}

Keberadaan kain tenun cepuk sebagai warisan kebudayaan leluhur di wilayah Nusa Penida, Klungkung, Bali menghadapi berbagai persoalan pelik. Di tengah potensinya yang besar untuk memperkenalkan kain tenun khas Nusa Penida, Kabupaten Klungkung, berbagai kendala-kendala pengembangan industri kerajinan ini menjadi penghambat yang serius. Berbagai kendala tersebut diantaranya adalah permodalan, jaringan pemasaran, dan pengorganisasian diri melalui kelompok pengerajin. Muara dari semua itu adalah belum terbangunnya secara kuat komitmen kemitraan dari pengerajin sendiri, pemerintah, swasta, dan pelaku industri pariwisata untuk bergandengan tangan dan bersama-sama mengembangkan industri kerajinan kain cepuk di kawasan Nusa Penida, Kabupaten Klungkung, Bali. 
Industri kerajinan kain tenun cepuk Nusa Penida adalah salah satu sektor industri yang cocok untuk dikembangkan di daerah perdesaan. Berbasis kepada industri kerajinan rumah tangga masyarakat perdesaan, kerajinan kain tenun cepuk ini berkembang secara perlahan dengan ruang lingkup wilayah yang terbatas di wilayah Nusa Penida Kabupaten Klungkung dan Provinsi Bali tentunya. Seperti layaknya industri kecil kerajinan, persoalan permodalan menjadi persoalan yang sangat penting. Sebagai usaha kerajinan tangan, daya serap tenaga kerja sebenarnya sangatlah besar. Banyak penduduk pedesaan yang masih menyandarkan hidupnya kepada industri kerajinan ini. Namun persoalan pemasaran kain tenun ini yang tidak dikembangkan secara maksimal membuat usaha kerajinan tenun ini seperti jalan ditempat. Yang tidak kalah pentingnya adalah minimnya perhatian dan pelatihan dalam program-program pengembangan ketrampilan dalam mengerjakan kain tenun cepuk.

Usaha pemberdayaan dalam konteks keberpihakan pemerintah kepada masyarakat sangatlah diperlukan untuk pengembangan usaha kecil dan menengah yang berbasis rumah tangga. Strategi pemberdayaan dengan memanfaatkan potensi lokal mereka merupakan salah satu strategi pembangunan yang diimplementasikan dan dikembangkan dalam kegiatan pembangunan terutama negara-negara berkembang. Pemberdayaan adalah pemberian kewenangan dan pengembangan kapasitas masyarakat. Pemberian kewenangan dan pengembangan kapasitas tidak dapat dipisahkan. Ini disebabkan apabila masyarakat hanya memperoleh kewenangan tapi belum mempunyai kapasitas maka yang dihasilkan tidaklah maksimal.

Begitu juga yang terjadi pada pengerajin kain tenun cepuk di Kecamatan Nusa Penida. Secara kemampuan para pengerajin kain cepuk di Nusa Penida sangatlah luar biasa. Mereka mempunyai kewenangan sebebasbebasnya untuk mengembangkan kerajinan ini sesuai dengan kemampuan dan keinginan mereka. Para pengerajin ini mampu mempertahankan warisan budaya nenek moyang berupa kain cepuk. Namun, kapasitas mereka untuk mengembangkan kerajinan ini masih harus terus ditingkatkan terus menerus agar bisa menjadi industri kerajinan yang menghidupi masyarakat pengerajinnya. Oleh karena itulah pengembangan institusi lokal sebagai media pemberdayaan dan kewirausahaan masyarakat menjadi sangat strategis. Penguatan institusi lokal dapat menjadi sarana pengambilan keputusan bersama dan kontrol terhadap sumberdaya, sedangkan ke luar sebagai sarana dan media menjalin hubungan dengan berbagai stakeholder baik pemerintah maupun non-pemerintah (Soetomo, 2011: 91).

Artikel ini menggambarkan kompleksitas persoalan yang dihadapi oleh industry kecil kain tenun cepuk di Nusa Penida (Desa Pejukutan dan Desa Tanglad) dan menawarkan model-model pemberdayaan yang bisa dikembangkan untuk meningkatkan kapasitas industri kecil ini dan membangun sinergitas yang berkesinambungan antara berbagai komponen masyarakat (pemerintah, swasta, dan industri pariwisata) yang memiliki potensi sangat besar untuk memajukan industri kerajinan kain tenun cepuk ini.

\section{METODE}

Penggalian data dilakukan dengan metode kualitatif yang emansipatoris dan partisipatif. Perspektif emansipatoris dengan dengan menempatkan potensi usaha kerajinan yang berbasiskan komunitas masyarakat tempatan sebagai subjek. Dengan demikian, menggunakan perspektif masyarakat tempatan menjadi subjek sangatlah penting dari mulai mengenali persoalan hingga menghasilkan program-program pemberdayaan yang mereka kehendaki bersama. Ini tentunya sejalan dengan pendekatan ekonomi kerakyatan dan bottom up yang menjadi paradigm pemerintah dalam mengedepankan usaha kecil dan menengah agar dapat bersaing di pasar nasional bahkan internasional. Dengan demikian masyarakat benar- 
benar berdaya dan menjadi subjek langsung yang mengelola tata pengelolaan perekonomiannya, dalam hal ini secara khusus adalah usaha kerajinan kain tenun cepuk.

\section{HASIL DAN PEMBAHASAN}

Konsep pemberdayaan memberikan tekanan pada otonomi pengambilan keputusan dari suatu kelompok masyarakat, yang berlandaskan pada sumber daya pribadi, secara langsung melalui partisipasi, demokratis dan pembelajaran sosial melalui pengalaman langsung. Sebagai titik fokusnya adalah "lokalitas" dengan asumsi bahwa 'civil society' siap diberdayakan melalui issueissue lokal. Namun Friedmann mengingatkan, bahwa tidak realistis apabila kekuatan ekonomi dan struktur diluar civil society diabaikan, karena pemberdayaan tidak semata-mata di bidang ekonomi, tetapi juga secara politik, sehingga ma-syarakat akan memiliki 'bargaining position' secara nasional ataupun internasional.

Pemberdayaan masyarakat dalam pembangunan merupakan upaya untuk meningkatkan memandirikan, keswadayaan dan keberdayaan masyarakat sesuai dengan potensi yang dimilikinya secara utuh dan komprehensif guna meningkatkan harkat dan martabat lapisan masyarakat yang dalam kondisi sekarang tidak mampu melepaskan diri dari kesenjangan dan keterbelakangan, menjadi upaya me-mampukan dan memandirikan masyarakat. Kemandirian adalah kemampuan mengakomodasi sifatsifat baik manusia untuk ditampilkan di dalam sikap dan perilaku yang tepat berdasarkan situasi dan kondisi yang dihadapi oleh seorang individu. Individu yang memiliki kemandirian akan memiliki dan menunjukkan sifat dan sikap rajin, senang bekerja, sanggup bekerja keras, tekun, berdisiplin, berani berebut kesempatan, jujur, mampu bersaing dan mampu pula bekerjasama, dapat di percaya dan mempercayai orang lain, tidak mudah putus asa dan berusaha mengenali kelemahan dan kekurangannya dan berusaha menolong dirinya sendiri tanpa bergantung pada orang lain . Atau kemandirian merupakan sikap dan perilaku yang dapat mengantarkan manusia untuk meraih sukses yang sebesar-besarnya dalam menjalani hidup dan kehidupan bersama dengan orang lain. Itulah sebabnya, kemandirian merupakan suatu paradigma pembangunan sebagai antitesis dari paradigma ketergantungan (Hettne, 1985).

Sebagai warisan budaya leluhur, kain tenun cepuk merupakan ciri khas dari daerah Nusa Penida Kabupaten Klungkung, Bali. Dua desa yang sangat dikenal menjadi pengerajin kain cepuk adalah Desa Tanglad dan Desa Pejukutan yang teletak di pegunungan tengah Pulau Nusa Penida. Desa Tanglad kini menjadi sentra produksi kain tenun cepuk dan beberapa menyebar ke Dusun Karang Desa Pejukutan. Kesucian, perlindungan, keindahan, kekuatan, kegaiban merupakan beberapa makna Kain Cepuk. Kain Cepuk dari asal katanya berarti "bertemu" atau "pertemuan", ini sesuai dengan penggunaaanya yang selalu melibatkan pertemuan orang banyak. Kain ini secara khusus dipergunakan oleh penjual sarana-prasarana persembahyangan "tukang banten", pengobatan tradisional "balian, dukun", tarian tradisional seperti Barong Rangda, Joged, Baris serta tarian Bali lainnya (Hauser-Schäablin, 1990).

Usaha-usaha pemberdayaan industri kain tenun cepuk di Desa Tanglad dan Desa Pejukutan Nusa Penida, Kabupaten Klungkung berdasarkan pada kepentingan lokal masyarakat yang menjadi penyokong utama dari industri kerajinan kain tenun warisan leluhur ini. Masyarakat lokal sebagai pengerajin sudah sangat lama menekuni kerajinan kain tenu cepuk ini, bahkan sebagian ada yang menjadikannya sebagai sumber penghasilan utama. Kadek Ida (27) tidak seperti perempuan dari Dusun Karang Desa Pejukutan kebanyakan yang menekuni kerajinan kain tenun cepuk hanya sampingan setelah berkebun. Ibu satu anak ini memutuskan untuk menggantungkan hidupnya dengan menenun kain cepuk. Hingga saat ini sudah 7 tahun ia menekuni kerajinan kain cepuk. 
Lain halnya dengan Men (lbu) Mandra (62) yang sangat setia dengan menggunakan alat tradisional cagcag dalam menenun kain cepuk. Bagi Men Mandra, ia tidak pernah kesepian dari pesanan kain cepuk dengan cagcag. Meski agak lama mengerjakan, para pemesan sudah mengetahui sebelumnya dan bersedia untuk menunggunya. Ratarata Men Mandra biasa menyelesaikan 1 kain dalam waktu 14 hari/2 minggu. Memang menenun kain cepuk tidak dia lakukan sepenuhnya. la terbiasa menenun setelah menyelesaikan pekerjaan rumah tangga, memberi makan babi, atau kalau ada metulungan (membantu warga lain jika ada ritual). Sehingga ia seperti biasanya baru biasa menenun pada sore hari. la biasa menjual kain cepuk cagcag yang dikerjakannya sekitar Rp.130 ribu150 ribu.

Diantara para pengerajin, ada beberapa diantara mereka telah aktif mengikuti pelatihan-pelatihan dan mempromosikan secara pribadi hasil kerajinannya kepada publik. Ambil contoh misalnya Ni Wayan Budiasih (38) yang mungkin menjadi salah satu pengerajin cepuk di Desa Tanglad yang telah eksis. la menggantungkan sebagian hidupnya dari penjualan kain tenun cepuk. Budiasih juga aktif untuk mengikuti pelatihanpelatihan di Kota Klungkung. Tercatat sudah 2 kali ia mengukuti pelatihan yang berlangsung atas inisiatif dari Dinas Perindustrian tersebut.

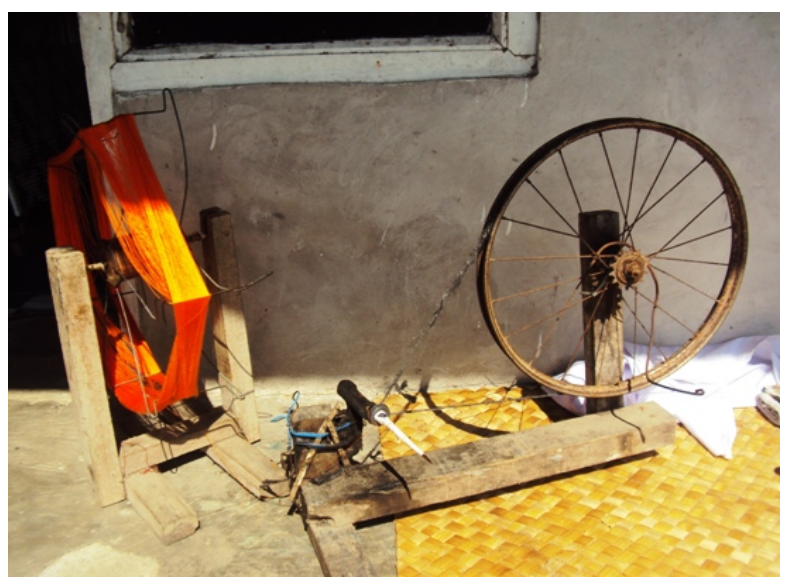

Gambar 1. Salah satu contoh alat untuk memproduksi kain tenun cepuk (foto: Luh Sayang Telagawathi)
Terakhir ia mengikuti pelatihan pewarnaan alam pada kain cepuk, bukan warna kimia seperti biasa dilakukannya. Namun Budiasih mengakui dengan pewarnaan alam jauh lebih rumit dan produksi yang dihasilkan lebih sedikit dan memakan waktu lama. Budiasih melihat, prospek dari kerajinan ini sangatlah besar. Untuk kain saja sebulan bisa berpenghasilan Rp. 800 ribu dan selendang Rp. 400 ribu. Promosi juga gencar dilakukan untuk memasarkan kain cepuk agar dikenal di luar Bali. Budiasih pernah ikut mengirimkan karya-karyanya dalam 2 kali pameran promosi di Jakarta khusus kain cepuk. Hingga kini Budiasih tidak tergantung kepada siapapun untuk proses pengerjaan kain cepuk. la mengisahkan bagaimana harus membeli peralatan seperti benang dan pewarnaan ke Desa Sampalan hingga sampai ke Kota Klungkung.

Ni Ketut Suartini, ketua pengerajin cepuk Bukit Lestari Nusa Penida yang mengungkapkan bahwa daerah Nusa Penida memiliki beberapa jenis kain tradisonal, seperti Cepuk, Rang-Rang serta kain Saudan. Cepuk merupakan jenis tenunan yang merupakan ciri khas daerah tersebut. Sama seperti halnya di Tenganan yang terkenal dengan kain Pegringsingannya.Begitu pula dengan kain rang-rang yang dibuat selendang, serta Saudan yang memiliki arti kain yang memiliki dasar motif yang pasti, namun kadang dibuat lepas dari motif kain yang sebenarnya. Masing-masing kain tersebut memiliki ciri khas sendiri-sendiri. Untuk Cepuk motifnya tidak bisa dirubah atau ditinggalkan dan itu merupakan keharusan. Motif yang ada pada Cepuk yaitu tembing, matan titiran, panggeh taji, odot (motif garis yang ada di atas maupun dibawah kain Cepuk), ada juga motif setengah gunung, kurung, pancit gengong dan semayut. "Motif-motif tersebutlah yang menjadi ciri khas Cepuk," ujarnya. Sedangkan, lanjutnya, motif pada kain Rang-Rang lebih banyak menggunakan motif Gunung dan motif Saudan lebih banyak motif garis. Untuk pewarnaan, diungkapkan, kain-kain tersebut umumnya menggunakan warna alami, namun seiring dengan perkembangan permintaan yang mengharuskan pihaknya memproduksi 
dalam waktu cepat, maka digunakan pula warna kimia.

Lebih jauh diungkapkan, untuk warna alami usaha pengerajin Bukit Lestari Nusa Penida hanya memproduksi beberapa saja, sebab dalam produksinya membutuhkan waktu yang cukup panjang, dari mulai proses pemintalan benang, pencelupan hingga menenun dan produk akhir. "Proses produksi kain warna alam seperti Cepuk misalkan, membutuhkan waktu hingga enam bulanan untuk membuat 2 lembar kamben ukuran 2,25 m X 1,10 m," ujarnya. Untuk kain Rang-rang, membutuhkan waktu pengerjaan sebulan untuk satu lembar kamben serta 20 hari untuk memproduksi satu buah selendang. Saat ini, pihaknya sedang mengerjakan 50 lembar kain Cepuk warna kimia, yang dipesan dari konsumen, dan 3 lembar kain yang sama namun menggunakan warna alami. "Jika kami menggunakan warna alam waktu lama, sehingga konsumen memilih menggunakan warna kimia disamping harganya juga terjangkau," kata Suartini. Menggenai harga, ditambahkan, bervariasi tergantung jenis serta bahan warna yang digunakan. Untuk sebuah Cepuk berupa kamben warna alam dijualnya mulai $\operatorname{Rp} 1,2$ juta-Rp1,5 juta per lembar, sedangkan yang berbahan kimia rata-rata Rp 150 ribu per lembar. Kain Rang-Rang berupa selendang dijual dengan harga $\mathrm{Rp} 300$ ribu-Rp 400 ribu per lembar, dan kain Saudan berkisar Rp 300 ribu-Rp 700 ribu per lembar.

Saat ini, kain-kain yang diproduksinya tersebut, selain dipasarkan di Bali juga di beberapa daerah di Indonesia. Seperti Jakarta, Jambi, Blitar, bahkan hingga ke Sumatera dan Sulawesi. "Kami sebagai perajin khususnya perajin kain tenun khas Nusa Penida akan terus berinovasi, selain mempertahankan ciri khas daerah, kami juga menciptakan motif-motif baru yang tentu saja tidak meninggalkan pakempakem kain tradisional yang sudah ada," imbuhnya.

Sebagian besar pengerajin cepuk yang mengeluh soal modal. Namun hal ini tidak berlaku bagi $\mathrm{Ni}$ Ketut Suartini. Ia berkeyakinan bahwa modal bukan hanya uang. Ini membawanya merintis karier pada 1990 menjadi pedagang kain tenun ikat cepuk khas Nusa Penida.

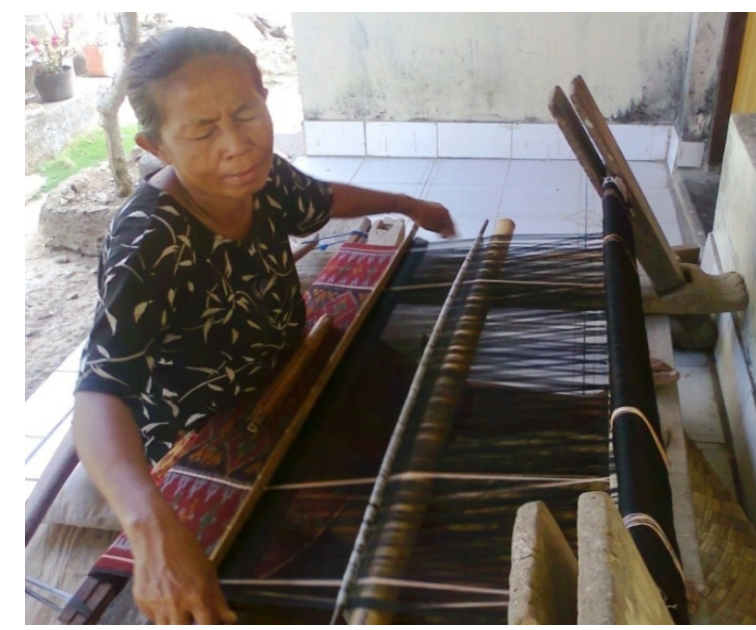

Gambar 2. Menenun kain cepuk tradisonal yang bernama cagcag

(foto: Luh Sayang Telagawathi)

"Saya tak punya modal berupa uang. Modal saya cuma dengkul dan nekat," tuturnya. Dengan dengkulnya, Suartini mulai menjajakan kain Cepuk hasil pinjaman dari perajin kain Cepuk di lingkungannya. Kain ini ditawarkan dari satu pintu ke pintu di berbagai wilayah Klungkung. Sengatan matahari, guyuran hujan, penolakan mentah-mentah, mewarnai perjalanan karier wanita kelahiran 4 September 1968 ini. "Saya memilih menjadi pengusaha Kain Cepuk demi melestarikan warisan budaya leluhur. Apalagi, kerajinan kain Cepuk hanya ada di Nusa Penida," ungkap istri Wayan Sukagama ini.

Setahun berjalan, dengan modal Rp 500 ribu, pada 1991 dia berhasil memproduksi kain Cepuk sendiri. Jangkauan pemasaran pun diperluas ke luar Nusa Penida seperti ke Denpasar, Gianyar dan Ubud. Kini usahanya kian mengepakan sayap. Suartini menerangkan, menggeluti usaha kain Cepuk itu gampang-gampang susah, apalagi kalau memproduksi untuk pesanan. Jika bahan baku mendadak melonjak naik dan stok bahan baku habis, maka kerugian tak bisa terlekakan. Hal ini terjadi karena penetapan harga biasanya ditentukan di awal sebelum kain pesanan diproduksi. Namun, kerugian bisa diantisipasi dengan menumpuk bahan baku. "Kita harus jeli membaca perubahan 
harga bahan baku. Jangan sampai rugi karena telanjur memutuskan harga sedangkan kita kehabisan bahan baku dengan harga lama saat bahan baku yang baru sudah naik," terangnya.

Dari berbagai keterangan yang disampaikan oleh para pengerajin industry kecil kain tenun cepuk di Nusa Penida (Desa Tanglad danDesa Pejukutan), dihadapkan kepada beberapa persoalan diantaranya secara garis besar adalah pemasaran, kualitas sumber daya manusia, dan lemahnya institusi lokal kelompok pengerajin kain tenun cepuk.

Model pemberdayaan kain tenun cepuk di pemasaran adalah kepada jaringan distribusi dan promosi. Diidentifikasi kurang lebih ada 4 pihak yang akan membangun sinergi untuk memberdayakan pemasaran kain cepuk. User-nya adalah pada pengerajin itu sendiri.

PEMERINTAH bisa melakukan aksi-aksi sesuai dengan kapasitasnya. Misalkan saja: Melakukan promosipromosi kain cepuk dalam pameranpameran industri dan kerajinan, Menginisiasi gebrakan agar pegawai Pemerintah Daerah Klungkung berseragam cepuk dan terus menerus mempromosikan kain cepuk dalam kegiatan-kegiatan pemerintahan yang dilaksanakan, dan membangun jaringan distribusi dan pemasaran melalui jalur pemerintahan.

SWASTA/PERUSAHAAN bisa melakukan model pemberdayaan dengan sistem bapak angkat yaitu memberikan subsidi dan pinjaman lunak kepada organisasi pengerajin cepuk. Hal lainnya adalah berupa bantuan permodalan dan kerjasama saling menguntungan antara pihak swasta/perusahaan dengan pengerajin.

INDUSTRI PARIWISATA secara spesifik menjadi salah satu actor yang bisa bersinergi untuk memberdayakan kerajinan cepuk. Diantara program aksi yang bisa dilakukan oleh komponen pariwisata di Nusa Lembongan dan Bali secara umum adalah: paket wisata ke pengerajin tenun cepuk di rumah-rumah penduduk di Tanglad dan Karang, promosi lewat jaringan wisata dan website hotel, pemesan kain cepuk oleh hotel- hotel untuk interior dan keperluan di hotel, kerjasama saling menguntungkan antara pihak hotel dengan pengerajin cepuk serta mengusulkan agar pakaian karyawan hotel adalah kain tenun cepuk.

Jaringan lokal dalam hal ini maksudnya adalah jaringan pemasaran yang selama ini telah dilakukan yaitu dari mulut ke mulut dan promosi kain tenun cepuk saat upacara keagamaan dan ritual-ritual lainnya.

Sinergi pemerintah, swasta dan industry pariwisata sangatlah penting untuk mengembangkan SDM pengerajin cepuk dengan serangkain pelatihanpelatihan yang selama ini telah dilakukan oleh pemerintah Kabupaten Klungkung lewat Dinas Perindustrian. Namun hal ini harus dilanjutkan oleh sinergi antara swasta dan industry pariwisata sehingga hasil dari pelatihan itu langsung dipraksiskan dengan serangkain kerjasama dengan swasta dan industri pariwisata dalam bidang pemasaran atau system bapak angkat misalnya. Peningkatan SDM kain cepuk bisa dilakukan dalam bidang: Manajemen bisnis, Pemasaran, dan Inovasi dan motof-motif (pewarnaan alam).

Melalui sinergi pemerintah, swasta dan pelaku industri pariwisata menjadi kekuatan yang penting untuk memperkuat posisi pengerajin dan memudahkan jaringan pemasaran. Ini dilakukan dengan membentuk institusi local dalam pespektif pemberdayaan yaitu kelompok-kelompok pengerajin. Peran kelompok pengerajin ini sangat strategis untuk menyatukan pengerajin-pengerajin di rumah tangga. Dengan dibentuknya kelompok-kelompok tani ini akan memperluas akses ke pemesanan kain cepuk oleh swasta/perusahaan, pemerintah dan industry pariwisata, sudah tentu pemasaran akan semakin luas dan intens serta akan muncul inovasi untuk pengembangan usaha ke depannya.

\section{SIMPULAN DAN SARAN}

Potensi usaha kerajinan kain tenun cepuk di wilayah Nusa Penida Kabupaten Klungkung Bali sangatlah besar. Sebagai warisan leluhur dan budaya lokal yang terkandung didalamnya, kain tenun cepuk memiliki peluang untuk dikembangkan 
lebih maksimal bagi pelestarian nilai-nilai kebudayaan fisik tersebut (kain cepuk) dan mendatangkan kesejahteraan bagi masyakarat lokal pendukung kebudayaan tersebut. Studi awal dalam laporan ini menggambarkan, melalui narasi para pelaku lokal dari kerajinan cepuk, kompleksitas persoalan yang dihadapi mereka untuk tetap bertahan menekuni kerajinan warisan leluhur ini.

Hasil studi ini menyimpulkan ada beberapa model-model pemberdayaan yang bisa diidentifikasi dari berbagai permasalahan yang dihadapi oleh kerajinan kain tenun cepuk ini. Beberapa model-model pemberdayaan tersebut adalah:

1. Model pemberdayaan pemasaran kain tenun cepuk. Pemasaran yang dimaksudkan adalah serangkaian proses promosi, distribusi, dan penjualan yang sistematis dan menjangkau pasar (konsumen) yang luas untuk memperkenalkan kerajinan kain tenun cepuk. Pemberdayaan pemasaran dilakukan dengan membangun kemitraan dengan pemerintah, swasta (perusahaanperusahaan), dan secara spesifik membangun networking dengan industri pariwisata.

2. Model pemberdayaan sumber daya manusia adalah peningkatan kualitas para pengerajin dengan melakukan serangkaian pelatihanpelatihan ketrampilan dan manajemen pengelolaan usaha. Diantara model pelatihan yang bisa dikembangkan adalah pelatihan manajemen bisnis, strategi pemasaran, dan secara praktis pelatihan-pelatihan motifmotif dan inovasi baru dalam mengembangkan kain tenun cepuk. Dalam hasil penelitian ini ditemukan dari hasil wawancara dengan Ni Luh Sari dan Ni Wayan Budiasih, bahwa usaha inovatif dalam pelatihan-pelatihan telah dilakukan Dinas Perindustriaan Kabupaten Klungkung melalui pelatihan warna alam dan pelatihan serta bantuan alat-alat ATBM (Alat Tenun Bukan Mesin) bagi pengerajin di Desa Tanglad Nusa Penida Kabupaten Klungkung. ${ }^{1}$

3. Model pemberdayaan kelompok pengerajin kain tenun cepuk. Kuatnya posisi pengerajin dalam lingkaran pemasaran adalah ketika mereka kelompok.

4. Penelitian ini juga mengidetifikasi model pemberdayaan kelompok pengerajin. Pemberdayaan ini dilakukan dengan kemitraan yang kuat antara pengerajin-pengerajin dari masyarakat lokal di Desa Tanglad, Pemerintah, swasta seperti perusahaan-perusahaan, dan secara khusus adalah pelakupelaku di industri pariwisata untuk secara intens dan khusus memperhatikan industry kerajinan kain tenu cepuk sebagai bagian dari salah satu jaringan industri pariwisata budaya di Bali.

Dari kedua model pemberdayaan yang dihasilkan dalam penelitian ini, untuk tindak lanjut pengembangan, terdapat dua persoalan penting yang menjadi muara pemberdayaan industry kerajinan kain tenun cepuk di Nusa Penida, Klungkung Bali. Dua persoalan itu adalah; pertama, mengembangkan strategi pemasaran yang bisa dikembangkan oleh masyaralat lokal Nusa Penuda berdasarkan potensi yang dimilikinya. Kedua, mengembangkan strategi pendampingan untuk pembentukan institusi lokal berupa kelompok pengerajin kain tenun cepuk yang kuat dan mampu menghimpun segala potensi lokal pengembangan kain tenun cepuk di Nusa Penida. Dua persoalan penting tersebut akan coba saya kembangkan dalam proposal lanjutan dari hibah bersaing ini untuk secara berkesinambungan memahami kompleksitas persoalan kain tenun cepuk dan berusaha mencari solusi pemberdayaan untuk mengembangkannya.

\footnotetext{
${ }^{1}$ Wawancara dengan Ni Luh Sari (14 Juni, 3 Juli dan 4 Juli 2011) dan wawancara dengan Ni Wayan Budiasih 6 Mei, 15 Juni dan 6 Juli 2011.
} 
Ada beberapa rekomendasi berupa langkah-langkah strategis yang bisa dilakukan pihak-pihak terkait dalam pemberdayaan industri kerajinan kain cepuk di Nusa Penida:

1. Pemerintah secara intensif memfokuskan untuk membangun kemitraan dengan swasta dan industri pariwisata untuk mempromosikan kain tenun cepuk dengan segala program-program di pemerintahan maupun dengan swasta dan pelaku pariwisata. Hal ini bisa dilakukan dengan programprogram inovatif seperti pemberlakuan kain cepuk sebagai kain khas Kabupaten Klungkung dan membangun kerjasama melalui pameran-pameran kerajinan di Indonesia.

2. Merekomendasikan pihak swasta dan perusahaan-perusahaan yang bergerak di industri tekstil dan perdagangan untuk membangun kerjasama dengan pengerajin lokal kain cepuk sebagai bapak angkat, mempromosikan, dan mencarikan peluang-peluang distribusi bisa mengembangkan pemasaran kain cepuk.

3. Kepada kalangan industri pariwisata di Kabupaten Klungkung (khususnya di daerah Nusa Lembongan yang bertetangga dengan Nusa Penida) bisa melakukan program-program kerjasama dengan pengerajin cepuk dengan paket field tour ke lokasi-lokasi pengerajin, mempromosikan dan mengenakan seragam kain cepuk bagi karyawan hotel.

4. Kepada para pengerajin kain cepuk untuk menyatukan diri dan membangun usaha-usaha secara bersama-sama untuk mengidentifikasi permasalahan dan mencari peluang-peluang solusi dalam berbagai hal (produksi, promosi, dan distribusi kain tenun cepuk) yang memungkinkan dikembangkan di Nusa Penida.

5. Pembentukan secara solid dan penguatan institusi local berupa kelompok pengerajin yang akan menjadi tulang punggung bagi segala proses produksi, pemasaran, dan juga promosi kain cepuk Nusa Penida.

\section{DAFTAR PUSTAKA}

Antara, Made. 1999. Dampak Pemerintah Terhadap Kinerja Perekonomian Bali: Pendekatan Social Accounting Matrix. Disertasi Doktor pada Program Pascasarjana Institut Pertanian Bogor.

Antara, Made. 2003. UKM Motor Penggerak Perekonomian di Era Otonomi Daerah. Makalah.

Anonim. 2004. Pameran Kerajinan Tradisional Bahan Dasar Tekstil,http://www.balipost.co.id

Antjok, J. 1995. Pemanfaatan Orga-nisasi Lokal untuk Mengentaskan Kemiskinan, dalam Kemiskinan dan Kesenjangan di Indonesia. Adytia Media Yogyakarta.

Bisnis Bali, 19 Agustus 2010. "Kain Cepuk Alami Nusa Penida Dijual hingga Rp 1,5 Juta per Lembar" dan "Ni Ketut Suartini Hanya Modal Dengkul"

Cook, S., and Steve, M. 1997. Pemberdayaan yang Tepat. PT. Elex Media Komputindo, Jakarta.

Djamali, Abdoel dan Sugiyarto. 2002. Pengembangan Usaha Kecil dan Menengah Melalui Pendekatan Klaster Agroindustri. Makalah Disampaikan dalam seminar nasional Meningkatkan Peran Agribisnis Usaha Kecil dan Menengah Untuk memperkokoh Ekonomi Nasional Faperta UGM. Yogyakarta. Agustus 2002

Friedmann, J. 1992. Empowerment: the Polities of Alternatif Development. Chambrige, Bllackwell, 1992.

Hauser-Schäablin, Brigitta, Marie-Lousie Nabholz-Kartaschoff, dan Urs Ramseyer, Textiles in Bali, Singapore: Periplus Editions, 1990

Hettne, B. 1982. Ironi Pembangunan di Negara Berkembang. Sinar Harapan, Jakarta. 
Irsan A., S. 1991. Industri Kecil, Sebuah Tinjauan dan Perbandingan, Edisi II, LP3ES, Jakarta.

Korten, D. 1988. Pembangunan Berdimensi Kerakyatan. Yayasan Obor, Jakarta.

Laksono, P.M, (2009) "Peta Jalan Antropologi Indonesia Abad Kedua Puluh Satu: Memahami Invisibilitas (Budaya) di Era Globalisasi Kapital". Pidato Pengukuhan Jabatan Guru Besar pada Fakultas IImu Budaya Universitas Gadjah Mada.

Mubyarto. 1999. Reformasi Sistem Ekonomi: Dari Kapitalisme Menuju Ekonomi Kerakyatan, Aditya Medya, Yogyakarta.

Mubyarto. $1994 . \quad K e s w a d a y a a n$ Masyarakat Desa Tertinggal, Aditya Media, Yogyakarta.

Pranarka, AMW dan Prijono, O.S. 1996. Pemberdayaan,

Konsep,
Kebijakan dan Implementasi. CSIS, Jakarta.

Rahardjo, Dawam. 1986. Transformasi Pertanian, Industrialisasi dan Kesempatan Kerja. UI-Press, Jakarta.

Sumodiningrat, Gunawan, 1999. Pemberdayaan Masyarakat dan Jaring Pengaman Sosial, Gramedia Pustaka Utama, Jakarta.

Soetomo, 2011. Pemberdayaan Masyarakat, Adakah Alternatif Lain?, Pustaka Pelajar, Yogyakarta.

Tambunan, Tulus, 1989, Mengapa Industri Kecil Penting Bagi Indonesia. Harian Suara Pembaruan, tanggal 12 Desember, Jakarta.

Tjokrowinoto, M. 1993. Politik Pembangunan: Sebuah Analisis, Konsep, Arah dan Strategi. PT Tiara Wacana, Yogjakarta. 